\title{
Rationed nursing care - conclusions from focus groups
}

Racjonowana opieka pielęgniarska - wnioski z grup fokusowych

\section{Eva Janikova ${ }^{1,2}$, Ilona Plevova ${ }^{1}$, Darja Jarosova ${ }^{1}$}

\begin{abstract}
'University of Ostrava, Faculty of Medicine, Department of Nursing and Midwifery, Czech Republic ${ }^{2}$ University Hospital Ostrava, Department of Nursing Care, Czech Republic
\end{abstract}

Darja Jarosova: 0000-0002-3032-3076

CORRESPONDING AUTHOR:

Eva Janikova

University of Ostrava, Department of Nursing and Midwifery Syllabova 19, 70300 Ostrava Vitkovice, Czech Republic email: eva.janikova@osu.cz Phone: +420604312622

STRESZCZENIE

Słowa kluczowe:

ABSTRACT

Key words:

\section{RACJONOWANA OPIEKA PIELEGNIARSKA - WNIOSKI Z GRUP FOKUSOWYCH}

Cel. Zbadanie za pomocą grup fokusowych głównych obszarów niedopełnienia opieki oraz zidentyfikowanie jak postrzegane są przyczyny, skutki i propozycje potencjalnych rozwiązań.

Metody. W początkowym etapie badania wybrano metodę doboru grupy fokusowej. Utworzono trzy grupy fokusowe zlożone z 25 pielęgniarek pracujących na oddziałach stacjonarnych placówek opieki zdrowotnej regionu Morawsko-Śląskiego.

Wyniki. Na podstawie analizy treści, wyodrębniono cztery kategorie: przyczyny i skutki niedopełnienia opieki, niedopełnienia w podejmowaniu interwencji oraz sugestie potencjalnych rozwiązań. Kategorie te zostały następnie podzielone na podkategorie. Przyczyny niedopełnienia opieki odnosiły się do osobowości pielęgniarki, osobowości pacjenta, systemu opieki zdrowotnej i systemu zarządzania. Niedopełnienia w podejmowaniu interwencji zostały podzielone na interwencje podstawowej opieki pielęgniarskiej, specjalistyczne interwencje podejmowane przez pielęgniarki oraz wspólne czynności. Skutki niedopełnienia opieki dotyczyły zarówno pacjentów jak i personelu. Sugestie potencjalnych rozwiązań zawierały zmiany w zarządzaniu i marketingu, jak również w edukacji pracowników służby zdrowia i w opiece nad pacjentem.

Wnioski. W odniesieniu do racjonowania opieki, jakość zapewnianej opieki zdrowotnej nie może narażać na ryzyko bezpieczeństwa personelu oraz pacjentów. Otwarta dyskusja na powyższe tematy może zaowocować znalezieniem innych potencjalnych rozwiązań które mogłyby być praktycznie wdrażane.

grupa fokusowa, interwencja pielęgniarska, racjonowana opieka, pielęgniarstwo, pielęgniarka ogólna

Aim. The focus groups aimed to outline the main areas of missed care and identify how the causes, effects and potential solution proposals are perceived.

Methods. For the initial part of the research, the focus group method was selected. Three focus groups were organized which comprised 25 nurses working in inpatient wards of healthcare facilities in the Moravian-Silesian Region.

Results. Based on the content analysis, four main categories were established: causes and consequences of missed care, missed interventions and suggestions for potential solutions. These were further divided into subcategories. The causes of missed care were related to the nurse's personality, patient's personality, healthcare system and management system. Missed interventions were classified into basic nursing care interventions, specialized interventions to be performed by nurses and common activities. The consequences of missed care affect both patients and the staff. The suggestions for potential solution included changes in management and marketing, education of healthcare professionals and patient care.

Conclusions. With respect to care rationing, the quality of care provided must not be compromised to a point where the safety of the staff and patients is at risk. Discussing these issues openly may result in search for other potential solutions that may be implemented in practice. 


\section{INTRODUCTION}

In the Czech Republic, healthcare is regulated, among others, by Act No. 372/2011 Coll. on health services and the terms and conditions for the providing of such services, which specifies the conditions and requirements for the process of assessing the quality and safety of care provided [1]. Care quality assessment is mainly concerned with safety of both patients (e.g. identification errors) and staff and may be related to the structure, process or outcome of a particular aspect of healthcare. According to the American Nurses Association, nursing quality indicators include, for example, pressure ulcer prevalence, patient falls, nosocomial infections and nursing staff satisfaction [2]. The World Health Organization estimates that patient care is associated with various rates of errors. Globally, one out of ten patients is thought to be affected by errors [3]. Similar facts have been reported by Kalisch, Landstrom and Williams [4] who classify patient errors as either an act of omission (e.g. infrequent change of incontinence products) or an act of commission (e.g. administering an incorrect medication). At the same time, they point to the fact that errors of omission are more difficult to recognize but have more serious consequences for the patient. Rationing of nursing care is associated with lack of resources (both personal and material).

\section{AIM}

The focus groups aimed to outline the main areas of missed care and identify how the causes, effects and potential solution proposals are perceived. The focus groups were part of a research project on rationing of nursing care with regard to the occurrence of nosocomial infections in healthcare facilities in the Czech Republic.

\section{MATERIALS AND METHODS}

For the qualitative part of the research, the focus group method was selected. According to Kamberelis and Dimitriadis [5], the technique uses group interaction to gather data on a specified topic of interest. Focus groups have the advantage of using group dynamics and interactions among participants for easier exploring of their attitudes, thoughts, etc. [6]. Semi-structured interviewing was selected; basic topics were defined and open-ended questions were proposed to be asked by the interviewer. Each focus group included two interviewers whose main role was to control or possibly guide the discussion, motivate the participants to be open, ensure that the rules are followed (no interruptions, enough time for full answers, equal involvement of all participants, etc.) [7]. The participants were staff members working in general wards (medical and surgical specialties) who could choose from three dates to participate in a session. One session lasted for a maximum of 90 minutes. Most authors (e.g. [8]) recommended a group size of five to eight participants. However, Morgan [9] points to the fact that the group size also depends on its composition (activity of individual participants, their interest in the topic, etc.), the circumstances and experien- ces of the interviewer. Therefore, the group may include as many as $15-20$ persons provided that, for example, it is a naturally occurring group. The focus groups comprised a total of 25 participants (Group $A=7$, Group B =6, Group $\mathrm{C}=12$ ). The number of focus groups in not strictly recommended or defined. Given the objective of the project, a decision was made to use three focus groups preceding the questionnaire survey that allowed for theoretical saturation. The focus groups met in November 2018. Group A and B sessions were held at the Faculty of Medicine, University of Ostrava; Group C participants agreed to meet in a hospital canteen. Selecting a suitable place for focus group sessions is crucial [10]. Each focus group session started with a welcome, refreshments, introductions, short dialogues to relax the atmosphere and clarification of basic terms (missed/rationed care, etc.). The participants were asked to choose any name they liked to be used during the focus group session to ensure their anonymity. For the focus group preparations and organization, a group interview proposal was used [11]. The entire focus group session was audio-recorded; moreover, the interviewers made notes of important points.

Alongside a quantitative survey, the focus groups contributed to a more detailed insight into care rationing issues. Another benefit was the participants' opportunity to share and legitimize possible negative feelings and experiences, which in the end turned out to be very important.

\section{PARTICIPANTS}

The three focus groups comprised general nurses working in various positions in inpatient wards of various specialties in the Moravian-Silesian Region. Most of them (23) were females; the remaining two participants were males. Their age ranged from 23 to 55 years and they had from 7 months to 31 years of experience as nurses. On the day of their planned focus group session, two participants apologized for not attending due to busy workload and family matters. Group A and B participants did not know one another as they worked in different wards and facilities. Group C comprised workers from a single ward.

The criteria for selecting focus group participants were (i) working in a general ward for adults in a Moravian-Silesian Region healthcare facility, (ii) being a practical/ general nurse and (iii) a willingness to participate actively and openly.

\section{DATA ANALYSIS}

After completion of focus group sessions, interview recordings were verbatim transcribed. The resulting text was subjected to content analysis. Prior to the analysis, the text was highlighted (parts related to research questions were color-marked) by two independent readers. Subsequently, the text was read through several times and the following categories were established: causes of missed care, missed interventions, consequences of missed care and suggestions for potential solutions. The analysis did not include data quantification; the focus groups aimed to obtain as many answers related to a particular topic/category as possible. 


\section{RESULTS}

Content analysis identified four categories of missed care, namely causes of missed care, missed interventions, consequences of missed care and suggestions for potential solutions. Within the categories, subcategories were specified. An important factor related to job satisfaction was the statement made by participants after focus group sessions were completed. Although not the primary goal of participation in focus groups, their expression of relief from workload and stress resulted from the opportunity to share the issues. As one female participant stated: "But it was a good meeting. I am a bit relieved that I am not alone in it..." [Group A, Nurse 6].

\section{Category 1: CAUSES OF MISSED CARE}

Within this category, the following subcategories were specified: the nurse's personality (personal and professional), healthcare system, management system and patient's personality.

\section{Nurse's personality}

Nursing care is provided by nursing staff whose main role is to take care of the needs of patients and their loved ones and to fulfill doctors' orders. The causes associated with the nurse's personality included professional characteristics such as education and the related unawareness of certain procedures, length of practice, failure to make data obtained from patients objective, "professional blindness" (accepting the established stereotypes) and practices incorrectly learned from other employers or schools (e.g. mentors). Personal characteristics were described as the nurse's tiredness, current health status, age, value system ("I consider some things important and some unimportant" [Group A, Nurse 5]), liking/disliking various patients, current aversion ("not looking forward to work" [Group B, Nurse 2], to some activities), fear for oneself (resulting from growing patient's aggression), uncollegiality, disrespect and early burnout (unsupportive of the management).

\section{Healthcare system}

The entire healthcare is based on a system that gives a certain framework and form to the care provided. It provides a legislative background for nursing care. The main issues mentioned as causes of missed care were mainly the number of patients per nurse, increasing paperwork, lack of competence, nurse shortage (resulting in less stringent requirements as to education, knowledge and skills of general nurses - "almost anybody is admitted to school or gets the job" [Group A, Nurse 3]), a lack of financial resources (for everyday operation, devices, aids, as well as staff remuneration), poor and unsystematic organization of care (acute cases staying in general wards, more dependent patients but the same number of staff, increasingly sophisticated interventions/procedures (quantity over quality), omnipresent acceleration ("everything in a hurry" [Group B, Nurse 5]), demand that acute patients have priority over less acute ones, "sharing" staff members by several wards (e.g. to move a patient to an operating room, poor coordination of patient admissions), staff work overload (due to 12-hour shifts, no breaks, excessive shifts and overtime), multiple work tasks at the same time (e.g. between 6 a.m. and 10 a.m.), frequent changes to aids, procedures or medications. Also mentioned were inadequate spatial arrangement (shortage of single rooms), inadequate care continuity (e.g. discharging a diabetic patient in the late afternoon). One of the causes mentioned was also pressure upon the profession applied by society (e.g. increasing the quality of care or professional expertise of the staff).

\section{Management system}

The system of managing workers or work organization is an integral part of job satisfaction and a factor directly affecting the quality of care provided. In this domain, the causes of missed care were inadequate management of a ward/department/hospital with no regular employee evaluation, expecting higher-than-average performance under all circumstances, no praise or appreciation. This also includes appreciation of nurses' work from doctors or appreciation of healthcare assistants from nurses, subsequently influencing workers' motivation. An important cause of missed care mentioned by the participants was inadequate communication, fear to admit errors (either by a nurse or the entire ward), and, for example, an audit being used as an instrument for sanctions and not the quality of care. Also mentioned was little support for team collaboration and thus disagreement within the workplace team, managers' rigidity in their approach to both employees and patients (a lack of managerial effort and support for innovation and improvements, omitting mental and spiritual needs by the management and thus a lack of support for workers' activity). As for work organization, the staff is overloaded (number of shifts), as mentioned above.

\section{Patient's personality}

Last but not least, a subcategory linked to the personality of patients themselves was defined. This includes the impact of liking/disliking somebody on a relationship, both on the side of workers and on the side of patients. The personality and characteristics of patients may be the cause of missed care. In that respect, the participants mentioned patients' emotional blackmail and self-centeredness, health and mental status (dementia, immobility, aggressiveness, acute confusion). One of the statements was: "Those not asking for care do not get it." [Group B, Nurse 4]. Another cause may be the patient's decision to refuse care. A role is also played by patients' expectations concerning the staff or healthcare facility resulting from media portrayal (medical dramas on TV) and the impression that paying for a premium room also means premium care. This is reflected in patients' behavior towards the staff which, in turn, negatively affects the healthcare worker's behavior towards patients. 


\section{Category 2: MISSED INTERVENTIONS}

Within this category, the following subcategories were specified: basic nursing care and specialized interventions to be performed by general nurses that cannot be delegated to healthcare assistants [12]. The third group is activities common to all strata of health professionals. Generally, the participants described missed interventions as those that do not directly threaten the patients' lives, those that are difficult to detect and check and those asked for by patients. Also mentioned was the overall acceleration of care that is negatively perceived by patients and that has an impact on the comprehensiveness and correctness of a particular activity (e.g. changing a wound dressing).

\section{Basic nursing care interventions}

Among interventions belonging to basic nursing care that may be performed by healthcare assistants, the participants identified the following ones as missed: personal hygiene in bedridden patients, in particular oral hygiene (including teeth and dentures), nail and hair care. This patient group also comprised those with limited motion (restrained patients) or those preparing for diagnostic-therapeutic procedures (e.g. women's hygiene prior to a gynecological exam). Another missed intervention mentioned was care for the skin of the entire body (not only predilection sites), actively offering fluids to dependent patients (hydration), allowing enough time for meals (including the use of a PEG feeding tube). With regard to pressure ulcer prevention, the missed intervention is repositioning, with repositioning intervals being deliberately extended in bedridden patients. Other missed interventions were the use of medications in "non-problematic" patients (or checking their use), ensuring patients' comfort (feeling warm - an extra blanket or socks), meeting individual needs (lifting fallen objects, opening a plastic bottle, looking for things, etc.), activation of partly or completely immobile patients, caring for dying or deceased patients.

\section{Specialized interventions}

Among interventions to be performed by unsupervised general nurses, the following were identified as missed: attending to patients' mental and spiritual needs and educating patients and their families (communication with patients and their families in general, introducing oneself to patients, informing them about the planned procedures - partly doctors' responsibilities). Also mentioned were administration of sufficient analgesics (continuous administration, pain scale reassessment after administration of analgesics), administration of inhalation agents, cleaning peripheral or central venous catheters after giving an infusion, changing leg dressings, adherence to intervals for patient monitoring as set by valid guidelines (e.g. monitoring of vital functions after procedures in stabilized patients, standard scale reassessment following each change of the patient's condition), filling in the data about patients in advance (i.e. without patients being present). The latter issue is related to patient documentation; the updates are commonly postponed to the end of a shift or entries are even made after the shift is over, with this overtime work not being recorded. Documentation is also related to discrepancies; for example, the patient's records state no invasive points of entry which is not true. Other missed interventions are device checks (e.g. to make sure infusion pumps work as they should), changing aids (e.g. infusion sets), patient identification in accordance with standards, pulmonary rehabilitation and general rehabilitation care, adherence to a preset work schedule during night shifts. Also missed are regular overall patient assessments (overall appearance, nutritional status, skin and mucosae, etc.) or communication with the family in general and, particularly, when the patient is discharged to be cared for at home (failure to ensure care continuity). The participants mentioned that therapeutic regimens (doctors' orders ) have priority over patients' own needs. One example was related to continuous infusion therapy and meeting the patient's basic physiological needs (plan of infusions with no time for the patient to go to a toilet or participate in rehabilitation activities. etc.). This stemmed from a lack of cooperation with doctors (who often do not realize the time limitations for patients and only see their side of care). The lack of cooperation is also noticeable during night shifts, as the participant stated that nurses were concerned about doctors' reactions to being disturbed during the night. Also reported were certain "bad habits" that help nurses work faster but are not consistent with recommended standards, such as marking syringe covers, preparing medications "in advance" (e.g. peripheral venous catheter wash, not indicating it).

\section{Activities common to all health professionals}

Activities common to health professionals of various specialties are those that cannot be classified based on competence as they overlap. It must be said that assessment of such missed activities was left to nurses as they participated in focus groups. These included the aforementioned care for patients' mental and spiritual needs (listening to them); in a way, this is an umbrella term for other activities as mentioned above: introducing oneself to patients (as a health professional), respecting patients' intimacy and privacy (e.g. during ward rounds), proper education of patients and supervision of their common habits (e.g. hygienic or dietary). Also mentioned were adherence to the principles of barrier nursing (hand hygiene and disinfection, use of personal protective equipment, especially disposable gloves, adherence to aseptic practices) and interdisciplinary cooperation (e.g. receiving information from simultaneous physiotherapy) as well as information about the frequency and course of visits to individual patients.

\section{Category 3: CONSEQUENCES OF MISSED CARE}

The consequences of missed care may be negatively perceived by both the staff (impacts on job satisfaction, team collaboration, safety) and patients (development of nosocomial infections, dissatisfaction with the quality of nursing care). 


\section{Healthcare staff}

The subcategory of consequences for the healthcare staff specifically included safety, either one's own or safety of one's colleagues, such as a higher probability of work accidents or transmission of infection (even potential threat to safety of one's family members). Crucial was the impact of missed care on nurses' burnout syndrome (emotional exhaustion, physical exhaustion, depersonalization). Specifically, the participants mentioned emotional dissatisfaction or even frustration, feelings of personal failure and inferiority ("I can't handle this. I will have to leave." [Group A, Nurse 2]), loss of motivation to do the job, physical tiredness. Also mentioned were impacts on interpersonal relations in the workplace (deterioration of relations in the team, conflicts between shifts, animosity, dissatisfaction transferred to new colleagues or possibly students in training) and growing feelings of fear (e.g. concerning documentation errors - "There will be omissions in the records." [Group C, Nurse 5]). Another impacts are exceeding one's competence (e.g. signing informed consent forms and subsequent harm to patients resulting from hiding some information from them) and unfinished work (bringing work home - "I keep thinking about my work at home" [Group A, Nurse 3] versus "I forget about it as soon I close the door" (Group B, Nurse 2]) or effects on nursing care as such (worsening of work continuity, underestimating the situation and consequences for the patient).

\section{Patients}

Once again, the subcategory of consequences for patients includes their safety - the risk of patient's harm, namely falls, pressure ulcers, thrombophlebitis and other complications from procedures such as the entire spectrum of nosocomial infections. As a result, extra work is generated (e.g. pressure ulcers require changes of dressings and additional nursing care), costs increase (longer hospital stays), etc. Missed care also influences patients' mental status, namely their overall dissatisfaction with care, more fear experienced, need for more attention, increase in complaints, social isolation of patients, development of hospitalism. Along with patients, their families may also be dissatisfied as they miss, for instance, personal communication.

\section{Category 4: SUGGESTIONS FOR POTENTIAL SOLU- TIONS}

Within this category, the participants suggested how missed care could be solved or prevented, both in the area of management/marketing and in the area of nurse education and patient care. The suggestions included more respect (doctors' respect for nurses, managers' respect for nurses as well as nurses' respect for patients) or support for work as such ("so that nurses do things with love" [Group A, Nurse 6]).

\section{Management and marketing}

Within the management and marketing subcategory, the suggestions included shift overlap during the busiest hours (between 6 a.m. and 10 a.m.), consistent application of group care for patients, motivation of employees by the ward and hospital management, motivation through employee benefits (e.g. wellness recovery holidays or more days off work, not only simple income increase), support for team collaboration, selecting and supporting managers with lots of personality (e.g. by providing training in management, "so that managers are real managers" [Group B, Nurse 3]). This is associated with promoting mutual respect among all positions (managers and doctors respecting nurses' work), promoting good relations between doctors and nurses. The system of sanctions was also considered (e.g. an audit should be an opportunity to improve the quality of care rather than an instrument for sanctioning individuals or teams). This domain could also include changes to the healthcare system such as increasing the numbers of personnel, shorter working hours (reducing 12-hour shifts), electronic documentation (or its potential elimination). Suggestions concerning healthcare facilities include working environment adjustments (available and accessible rest - breaks when nurses are not disturbed by anything or anybody), sharing experiences by wards or hospitals, collaboration within multidisciplinary teams (use of psychologists and educational workers).

\section{Education of healthcare professionals}

One of the suggestions for improvement was education - an emphasis was put on lifelong learning of nurses in selected areas of knowledge or interesting and current topics. This, in turn, would lead to possible increase in competence (or, more precisely, clear definition of competence and adhering to it by all those involved, task delegation), guideline verification and updates ("Are care standards really properly set?” [Group B, Nurse 2]). The subcategory also involves education of future nurses, with the participants mentioning the role of mentors (their selection, prestige, appreciation), contributing to the students' attitude towards the profession.

\section{Patient care}

Within the patient care subcategory, the participants suggested that the family should have unlimited access to the patient and should be involved in patient care as early as during the hospital stay. The number and frequency of family visits should be entered in the patient's documentation. More attention should be paid to education of patients and their relatives.

\section{DISCUSSION}

\section{CAUSES OF MISSED CARE}

According to Winsett et al. [13], the most frequent causes of missed care are staff shortage, unexpected/ unplanned events (e.g. acute patient deterioration) and unavailable medications. Higher numbers of patients per nurse and more frequent missed care were also reported in a study by Cho et al. [14] showing a significant correlation. In addition to the number of staff, the authors 
also stated that working overtime increases the probability of missed care. This is related to resources in general (mainly personal but material as well), also mentioned as one of the causes of missed care by Henderson et al. [15]. Very similar opinions on the causes of missed care were expressed by focus groups participants in the present study who believed that they stem from the Czech healthcare system and the way it is set up. They also thought that staff shortage was linked to poor organization of care ("sharing staff members by several wards" [Group A, Nurse 5]), acute cases staying in general wards, etc.). Moreover, staff shortage is associated with education, resulting in omitting selected nursing intervention. Another reported cause of missed care was nurses' personal characteristics (value system, likes/dislikes). Consistently with Henderson et al. [15], the focus group participants attributed missed care to the management system, particularly a lack of regular employee evaluation by the management or a lack of appreciation of nurses' work from both managers and doctors. Another cause of missed care was the patient's personality reflecting their health and mental status, expectations and personal characteristics.

\section{MISSED INTERVENTIONS}

According to Kalisch et al. [16], the most frequently missed interventions are those that are the least likely to be revealed or those requiring collaboration with other workers who may not be available. The focus group participants most commonly mentioned interventions not directly threatening the patients' lives, those related to rehabilitation, care for bedridden patients (repositioning, oral hygiene). Similarly, other authors [13] reported oral hygiene, drug administration as ordered by doctors (within 30 minutes from the order). This is consistent with results from a study by Hernández-Cruz [17] who, apart from oral hygiene, reported patient ambulation three times a day and feeding patients while the food is warm. The focus group participants linked oral hygiene to the values system, stating that for many nurses, this intervention is generally not important (the role is played by the staff's personal views rather than by a lack of time). According to Kalisch [18], the most frequently missed interventions are related to monitoring, with the focus group participants giving an example of medication use monitoring. Consistently with most foreign studies, one of missed interventions was patient education during his/ her hospital stay. Generally, both studies and focus groups suggestions showed that interventions ordered by doctors are preferred to satisfaction of psychosocial and spiritual needs of patients.

\section{CONSEQUENCES OF MISSED CARE}

A study by Ball et al. [19] showed a higher risk of patients' deaths associated with an increase in missed care (a $10 \%$ increase in missed care means a $16 \%$ increase in the risk of patient death within 30 days of hospital stay). According to Kalisch [20], even minor omissions of care may lead to complications resulting in prolonged and costly recovery. This was confirmed by focus groups in the present study suggesting that missed care resulted in various patient complications associated with nursing interventions such as thrombophlebitis (due to peripheral venous catheter use), pressure ulcers (due to less frequent repositioning), etc. In a wider context, inadequate physical activity may also affect the physical and psychological well-being of patients, their lower stress load [21,22]. Apart from these, other consequences are lower patient's satisfaction with care provided and thus more complaints or prosecutions. Similarly, Jones, Hamilton and Murry [23] linked missed care to lower patient satisfaction, more adverse events, lower job satisfaction and higher nurse turnover. Also the focus group participants stated consequences related to health professionals. Apart from nurses' own safety (a higher probability of work accidents), they mentioned increasing frustration, feelings of personal failure and inferiority, consistently with numerous other studies $[20,24,25]$.

\section{SUGGESTIONS FOR POTENTIAL SOLUTIONS}

Cho et al. [14] stated that a potential solution may be recruiting more staff, subsequently leading to increased quality of care provided and better patient's safety. Apart from the number of staff, Ball et al. [19] reported consistent education of nurses (bachelor's degree), potentially having a direct and not negligible impact on patient mortality rates. Similar outcomes were reported by West et al. [26]. Both undergraduate and postgraduate or lifelong education of nurses was also mentioned by nurses in the present study. In that context, the role of mentors, their selection, position and function were considered important for both nursing students and new employees. Other suggestions included participation of the family in patient care which is determined by good communication between the staff and the patient and their family, together with their proper education.

The advantage of focus groups was the opportunity to share opinions which appeared to be beneficial for most participants. Similar benefits of focus groups were stated by Papastavrou and Andreou [27]. This finding reveals one of possible topics concerning care for nurses, namely regular supervision that would offer a chance to share feelings and experiences.

\section{CONCLUSIONS}

Missed nursing care is becoming an increasingly important issue leading to numerous discussions. This is contributed to by both patients demanding professional healthcare provision and increasingly pointing to various types of misconduct, and healthcare professionals, currently lacking almost everywhere $[28,29]$. Nursing care rationing tends to be associated with higher job dissatisfaction experienced by the staff, leading to higher turnover rates and an increasing shortage of nurses. Nursing care rationing is unlikely to disappear completely as it is an interplay of factors. However, there has to be a boundary indicating that care of sufficient extent and quality is provided so that neither patients' nor nurses' and nursing staff's safety is put at risk. Therefore, it is essential to prevent a further decrease in care quality, which means discussing 
these issues openly, supporting high quality education of health professionals and considering potential steps that might positively influence implicit rationing of care.

\section{REFERENCES}

1. ČESKO. Zákon č. 372/2011 Sb. ze dne 6. listopadu 2011, o zdravotních službách a podmínkách jejich poskytování (zákon o zdravotních službách). In Sbírka zákonů České republiky. 2011, částka 131. s. 4730-4801. Available: https://aplikace.mvcr.cz/ sbirka-zakonu/ViewFile.aspx?type $=z \& i d=23497$

2. Válková M. Hodnocení kvality poskytovaných zdravotních služeb. Praha: IPVZ, 2015.

3. Podstatová R, Chocholáč D. Ukazatele kvality ve zdravotnictví [online]. @ 2019, [cit. 2019-24-09]. Available: http://www.stapro.cz/ukazatele-kvality-ve-zdravotnictvi/.

4. Kalisch JB, Landstrom G, Williams RA. Missed Nursing care: Errors of ommision. Nurs Outlook. 2009;57 (1): 3-9.

5. Kamberelis G, Dimitriadis G. Focus Groups. In Denzin, N. K., Lincoln, Y. S. Collecting and Interpreting Qualitative Materials. 3rd ed. Sage Publications, 2008. p. 375-402.

6. Stewart DW, Shamdasani PN. Focus groups: theory and practice. 3th ed. SAGE Publications, 2015.

7. Miovský M. Kvalitativní prístup a metody v psychologickém výzkumu. 1. vyd. Praha: Grada, 2006.

8. Krueger RA, Casey MA. Focus Groups: A Practical Guide for Applied Research. 5th ed. SAGE Publications, 2014.

9. Morgan DL. Ohniskové skupiny jako metoda kvalitativního výzkumu. 1. vyd. Boskovice: Nakladatelství Albert, 2001.

10. Švaříček R, Šed'ová K. a kol. Kvalitativní výzkum v pedagogických vědách. 2 . vyd. Praha: Portál, 2014.

11. Hendl J. Kvalitativní výzkum: základní metody a aplikace. Praha: Portál, 2016.

12. ČESKO. Ministerstvo zdravotnictví. Vyhláška č. 391/2017 Sb. ze dne 16. listopadu 2017, kterou se mění vyhláška 55/2011 Sb. 0 činnostech zdravotnických pracovníků a jiných odborných pracovníků, ve znění vyhlášky 2/2016 Sb. In Sbírka zákonů České republiky. 2017, částka 137. s. 4360-4375. Available: https://aplikace.mvcr.cz/sbirkazakonu/ViewFile.aspx?type $=z \& i d=62503$

13. Winsett RP, Rottet $K$, Schmitt A, et al. Medical Surgical Nurses describe missed nursing care tasks - Evaluating our work environment. App Nurs Res. 2016; 32: 128133.

14. Cho E, Lee NJ, Kim EY, et al. Nurse staffing level and overtime associated with patient safety, quality of care, and care left undone in hospitals: A cross-sectional study. Int J Nurs Stud. 2016; 60: 263-271.

15. Henderson J, Willis E, Blackman I, et al. Causes of missed nursing care: qualitative responses to a survay of Australian nurses. Labour \& Industry: a journal od the soucial and economic relations of work. 2016; 26 (4): 281-297.

16. Kalisch BJ, Tschannen D, Lee $H$, et al. Hospital variation in missed nursing care. Am J Med Qual. 2011; 26 (4): 291-299.

17. Hernández-Cruz R, Moreno-Monsiváis MG, Cheverría-Rivera $S$, et al. Factors influencing the missed nursing care in patients from a private hospital. Rev LatAm Enfermagem. 2017; 25: 2877-2885.

18. Kalisch BJ. Missed Nursing Care A Qualitative Study. J Nurs Care Qual. 2006; 21 (4): 306-313.

19. Ball JE, Bruyneel L, Aiken LH, et al. Post-operative mortality, missed care and nurse staffing in nine countries: A cross-sectional study. Int J Nurs Stud. 2018; 78: 10-15.

20. Kalisch JB. Errors of omission: how missed nursing care imperils patients. Silver Spring: American Nurses Association, 2016.

21. Laňková J, Raboch J. Deprese. Doporučený postup pro všeobecné praktické lékaře. Praha: Společnost všeobecného lékařství ČLS JEP, 2013.

22. Kalisch JB, Xie B, Dabney B. W. Patient-reported missed nursing care correlated with adverse events. Am J Med Qual. 2014; 29 (5): 415-422.

23. Jones TL, Hamilton $P$, Murry N. Unfinished nursing care, missed care, and implicitly rationed care: State of the science review. Int J Nurs Stud. 2015; 52 (1): 1121-1137.

24. Vanfosson $C A$, Jones $\mathrm{TL}$, Yoder KH. Unfinished nursing care: An important performance measure for nursing care systems. Nurs Outlook. 2016; 64 (2): 124-136.

25. Blackman I, Henderson J, Willis $E$, et al. Factors influencing why nursing care is missed. J Clin Nurs. 2015; 24 (1-2): 47-56.

26. West $E$, Baron DN, Harrison D, et al. Nurse staffing, medical staffing and mortality in Intensive Care: An observational study. Int J Nurs Stud. 2014; 51 (5): 781-794.

27. Papastavrou E, Andreou P. Exploring sensitive nursing issues through focus group approaches. Health Sciences Journal. 2012; 6 (2): 185-200.

28. BartůňkováM,JarkovskýJ,DušekL.Personálníkapacityvčeskémzdravotnictví[online]. (C) 1995 - 2019, poslední aktualizace 24. 9. 2019 [cit. 2019-24-09]. Available: from: https://www.uzis.cz/system/files/nzis_rep_2018_E01_Personalni_kapacity _2017.pdf
29. Svoboda M. Nejzávažnějším problémem českého zdravotnictví je nedostatek kvalifikovaných zdravotníků v nemocnicích [online]. @ 1995 - 2019 ASO, [cit. 201924-09]. Available: https://www.asocr.cz/obsah/54/nejvaznejsim-problememceskeho-zdravotnictvi-je-nedostatek-k/21975.

Manuscript received: 01.10 .2019

Manuscript accepted: 23.10.2019

Supported by project NV18-09-00420 Rationing of nursing care as one of indicators of the occurrence of nosocomial infections and other adverse effects in hospitalized patients. All rights reserved in accordance with intellectual property regulations.

\section{ETHICAL ASPECTS}

The research and its methodology was approved by the Ethics Committee of the Faculty of Medicine, University of Ostrava. All focus group participants were informed about the research process throughout the entire project, the purpose of focus groups and gave consent to audio-recording the sessions. 